\title{
EFEKTIFITAS AIR KELAPA (Cocos nucifera L.) PADA PRODUKSI JAMUR MERANG (Volvariella volvaceae) DENGAN MENGGUNAKAN MEDIA ALANG-ALANG (Imperata cylindrica L.)
}

\author{
Masda Erfia Roza ${ }^{1}$; \& Mades Fifendy ${ }^{2}$ \\ ${ }^{1}$ Program Studi Pendidikan Biologi STKIP PGRI Sumatra Barat \\ ${ }^{2}$ Jurusan Biologi Universitas Negri Padang \\ Corresponding Author: \\ masdaroza08@gmail.com
}

\begin{abstract}
Straw mushroom (Volvariella volvaceae) is a fungal fruiting bodies and white eggshaped, brown, to black. Mushroom is used as a vegetable that has the nutrients, tastes good and beneficial to health such as preventing anemia or anemia. This study aimed to determine the effect of coconut water (Cocos ncifera L.) at medium reeds (Imperata cylindrica L.) on the production of edible mushroom (Volvariella volvaceae). This study was conducted in village of Malintang skelter, District Six Lingkung Sicincin. The study design was a completely randomized design (CRD) with 4 treatments and 4 replications. Obtained from the treatment of the large number of fungi per rack range 1-5 pieces. Wet weight per shelf fungi ranged from 33.2 to 166.5 grams and the largest mushroom body circle each shelf range $1-2,5 \mathrm{~cm}$. The results showed that the addition of different concentrations of coconut water very significant effect on the number of each shelf fungi, wet weight and body fungus largest circle on the level of 5\%. Giving coconut water concentration gives a significantly different effect on the large number of body wet weight of fruit and growing every shelf while the body of the loop does not affect the real fruit. Ari treatment using coconut (Cocos nucifera L.) as much as $150 \mathrm{ml}$ gave the best results on the production of edible mushroom (Volvariella volvaceae).
\end{abstract}

Key Word: Air Kelapa, Alang-alang, Jamur Merang

PENDAHULUAN

Jamur merang adalah jamur yang berbentuk payung dan tubuh buah berdaging. Pertumbuhan dan perkembangan jamur merang dipengaruhi oleh berbagai faktor lingkungan abiotik, yaitumenghendaki suhu udara $30^{\circ}-38^{\circ} \mathrm{C}$, kelembaban 80 -
$90 \%$, dan derajat keasamannya 6,8-7

(Sumiati dan Djuariah, 2007).

Jamur merang tergolong jenis jamur hangat (warm mushroom), karena mampu hidup pada suhu $30^{\circ}$ sampai $38^{\circ} \mathrm{C}$. Jamur merang juga digolongkan sebagai jamur kompos, karena tumbuh di media limbah organik atau limbah pertanian yang memiliki 
derajat keasaman $(\mathrm{pH})$ 6,8 sampai 7 . Jamur merang tidak tahan terhadap terpaan sinar matahari secara langsung. Namun, agar pertumbuhannya optimal, jamur tetap membutuhkan cahaya matahari (Suharjo, 2010).

Menurut Nurman dan Abdul (1982) dalam Laili(1997), faktor yang mempengaruhi pertumbuhan dan perkembangan jamur merang diantaranya adalah media penanaman jamur merang itu sendiri. Beberapa syarat yang harus dipenuhi media yang digunakan adalah: 1) cukup kandungan karbonnya dalam bentuk karbohidrat, 2) cukup kandungan nitrogennya dalam bentuk garam amonium yang nantinya akan dirubah menjadi protein. Media tersebut juga memiliki kadar kalsium yang penting untuk menetralkan asam oksalat yang dikeluarkan oleh miselium. Organisme hidup memerlukan hormon untuk pertumbuhannya, namun selain hormon pertumbuhan terdapat juga zat-zat yang dapat menghambat pertumbuhan, zat ini dapat menekan pertumbuhan berbagai organ vegetatif tumbuhan (Novi \& Rizki, 2015).

Secara alami, sebagai tanaman yang tidak memiliki klorofil (zat hijau daun), jamur merang hidup dari sisa tumbuhan yang sudah mati dan limbah pertanian atau pabrik yang mudah ditemukan di sekitar kita. Media tanam jamur merang diantaranya jerami, limbah kelapa sawit, ampas sagu, ampas batang aren, ampas aren,ampas tebu, sisa kapas, kulit buah pala, limbah biji kopi, limbah pabrik kertas, alangalang, tongkol jagung, eceng gondok, daun pisang kering, sisa tanaman kedelai (bagas), kertas puntung rokok dan kardus (Suharjo,2010).

Limbah hasil industri rumah tangga maupun pertanian sering menjadi masalah yang belum dapat terselesaikan dalam masyarakat. Limbah yang hanya dibakar atau ditimbun, akan menambah pencemaran lingkungan. Salah satu usaha untuk mengatasi masalah tersebut adalah dengan mengubah limbah menjadi media tumbuh jamur merang, limbah tersebut misalnya alang-alang.

Alang-alang merupakan tumbuhan pioner yang memiliki daya adaptasi tinggi sehingga sering mendominasi daerah-daerah bukaan baru. Alang-alang juga merupakan tumbuhan pengganggu yang menjadi masalah dilahan pertanian, terutama di perkebunan sawit dan karet. Alangalang mempunyai batang padat dengan buku yang berambut jarang, daunnya kasar dan bersifat cukup tinggi sehingga proses pelapukan agak lambat (Pusat Penelitian Karet Balai Penelitian 
Sembawa, 1996). Alang-alang yang mati akan membusuk pada permukaan tanah. Tanah lapisan atas yang merupakan hasil pelapukan ini dikenal juga sebagai tanah top soil yang sangat bagus untuk pertumbuhan tanaman (Rizki \& Novi, 2017).

Menurut Rosales dan Mew (1985) dalam Gusniwati (2008), kompos Alang-alang dibuat dengan bantuan jamur Trichoderma sp yang dapat mempercepat proses dekomposisi alang-alang menjadi humus Genus Trichoderma sp mempunyai potensi paling tinggi dalam perombakan bahan organik dibandingkan dengan jamurjamur perombak selulosa lainnya.

Indonesia merupakan salah satu penghasil kelapa terbesar di dunia. Banyak manfaat yang bisa diambil dari buah kelapa, diantaranya yaitu buah kelapa muda dapat dijadikan minuman yang segar dan bergizi, sementara daging buahnya yang sudah tua dapat dijadikan berbagai macam makanan maupun campuran berbagai masakan. Namun demikian, air kelapa dari kelapa yang sudah tua seringkali tidak dimanfaatkan secara optimal oleh masyarakat, melainkan hanya dibuang begitu saja sebagai limbah rumah tangga atau dibuang para penjual kelapa yang ada dipasar-pasar
Hasil penelitian bahwa air kelapa kaya akan potasium (kalium) hingga 17\%. Selain kaya mineral, air kelapa juga mengandung gula antara 1,7 sampa 2,6\% dan protein 0,07 hingga $0,55 \%$. Mineral lainnya antara lain natrium $(\mathrm{Na}), \quad$ kalsium $(\mathrm{Ca})$, magnesium $(\mathrm{Mg})$, ferum $(\mathrm{Fe})$, cuprum $(\mathrm{Cu})$, fosfor $(\mathrm{P})$, dan sulfur $(\mathrm{S})$. Disamping kaya mineral, air kelapa juga mengandung berbagai macam vitamin seperti asam sitrat, asam nikotinat, asam pentotenal, asam folat, niacin, riboflavin, dan thiamin. Terdapat pula 2 hormon alami yaitu auksin dan sitokinin sebagai pembelahan sel embrio kelapa (Anonimus, 2013).

Penggunaan air kelapa ini juga lebih baik dari pada menggunakan pupuk organik seperti NPK dimana pupuk anorganik ini menyebabkan ketidakseibangan hara dalam media bahkan pada penelitian Indriati et al (2013) penggunaan pupuk NPK untuk tanaman jagung memiliki hasil produksi yang rendah dari segi berat basah, jumlah biji dan diameter tongkol, dibandingkan dengan pemberian biofertelizer.

Fosfat adalah salah satu senyawa yang berfungsi untuk merangsang perkecambahan spora jamur. Sehingga ketersediaan fosfat dibutuhkan untuk 
pemanjangan hifa dan pembentukan tubuh buah jamur (Novi \& Rizki, 2015)

\section{METODE}

\section{Jenis Penelitian}

Jenis penelitian ini adalah eksperimen. Penelitian eksperimen dapat didefenisikan sebagai metode sistematis guna membangun hubungan yang mengandung fenomena sebab akibat. Pada penelitian ini dilakukan eksperimen pada pemanfaatan alangalang dan air kelapa sebagai media produksi jamur merang yang mana akan didapat hubungan sebab akibat antara penambahan konsentrasi air kelapa yang berbeda.

\section{Rancangan Penelitian}

$$
\begin{aligned}
& \text { Penelitian } \begin{array}{r}
\text { dilaksanakan } \\
\text { dengan metode } \\
\text { mengsperimen }
\end{array} \\
& \text { dan } 4 \text { ulangan: } \\
& \text { 1. Alang-alang ditambah air kelapa } 200 \\
& \text { ml }
\end{aligned}
$$

2. Alang-alang ditambah air kelapa 150 $\mathrm{ml}$

3. Alang-alang ditambah air kelapa 100 $\mathrm{ml}$

4. Alang-alang ditambah air kelapa $50 \mathrm{ml}$ Alang-alang yang digunakan pada secara keseluruhan sebanyak $2 \mathrm{~kg}$.

\section{HASIL DAN PEMBAHASAN}

\section{A. Hasil}

\section{Jumlah tubuh buah jamur} merang tiap rak

Hasil analisis sidik ragam dan uji BNJ terhadap jumlah tubuh buah jamur merang per rakmemperlihatkan

\begin{tabular}{|c|c|}
\hline Perlakuan & $\begin{array}{l}\text { Rerata jumlah } \\
\text { jamur (buah) }\end{array}$ \\
\hline $\mathrm{B}(150 \mathrm{ml})$ & 3,5 a \\
\hline $\mathrm{A}(200 \mathrm{ml})$ & $3 \quad a \quad b$ \\
\hline $\mathrm{C}(100 \mathrm{ml})$ & $\mathrm{b}$ \\
\hline $\mathrm{D}(50 \mathrm{ml})$ & 0,75 \\
\hline
\end{tabular}
pengaruh yang berbeda. Hasil jumlah tubuh buah tiap rak dapat kita lihat pada Tabel 1.

Tabel 1. Rerata jumlah jamur merang pada beberapa perlakuan air kelapa

Dari Tabel 1 dapatdilihat bahwa semua perlakuan memberikan pengaruh terhadap jumlah tubuh buah jamur merang tiap rak. Hal ini disebabkan sedikitnya konsentrasi air kelapa yang diberikan ke dalam media maka semakin sedikit pula jamur merang yang tumbuh. Jamur merang yang terbanyak tumbuh terdapat pada konsentrasi air kelapa $150 \mathrm{ml}$ (B) dan paling sedikit tumbuh atau bisa juga dikatakan tidak tumbuh sama sekali yaitu pada rak (D) karena diberikan konsentrasi air kelapa sebanyak $50 \mathrm{ml}$. 
Pemberian air kelapa dengan konsentrasi yang berbeda dapat berpengaruh terhadap jumlah tubuh buah jamur yang tumbuh.

\section{Berat basah jamur merang}

Berdasarkan data tersebut yang diperoleh, dari hasil analisis sidik ragam dan uji BNJ (Lampiran 2) didapatkan bahwa perlakuan yang diberikan yaitu berupa variasi konsentrasi air kelapa berpengaruh terhadap waktu panen dan dapat dilihat pada tabel 2.

Tabel 2. Rerata berat basah jamur merang pada beberapa perlakuan air kelapa

\begin{tabular}{|c|c|}
\hline Perlakuan & $\begin{array}{c}\text { Rerata berat } \\
\text { basah jamur (gr) }\end{array}$ \\
\hline $\mathrm{B}(150 \mathrm{ml})$ & 116,55 a \\
\hline $\mathrm{A}(200 \mathrm{ml})$ & 99,9 a b \\
\hline $\mathrm{C}(100 \mathrm{ml})$ & 74,15 \\
\hline $\mathrm{D}(50 \mathrm{ml})$ & 24,98 \\
\hline
\end{tabular}

Dari Tabel 2 dapat dilihat bahwa perlakuan memberikan pengaruh terhadap berat basah jamur merang dimana berat basah tertinggi terdapat pada perlakuan B yaitu $150 \mathrm{ml}$ dan perlakuan D menggunakan konsentrasi air kelapa sebanyak $50 \mathrm{ml}$ merupakan berat basah terendah. Respon auksin berhubungan dengan konsentrasinya. Konsentrasi yang tinggi dan yang sangat rendah bersifat menghambat, yang dapat dijelaskan sebagai persaingan untuk mendapatkan perletakan pada tempat kedudukan penerima, yang menyebabkan kurang efektifnya gabungan tersebut. Di samping itu, respon sangat bervariasi tergantung pada kepekaan organ tanaman. Batang merespon konsentrasi auksin dalam kisaran yang cukup lebar. Akar pada dasarnya terhambat pada hampir semua kisaran hormon Gardner (1991) dalam Armawi (2009).

\section{Lingkaran tubuh buah terbesar $(\mathrm{cm})$}

Hasil analisis sidik ragam dan uji BNJ dari lingkaran tubuh buah jamur memperlihatkan pengaruh tidak nyata. Hasil lingkaran tubuh buah dapat kita lihat pada tabel 3.

Tabel 3. Rerata lingkaran tubuh buah jamur merang pada beberapa perlakuan air kelapa

\begin{tabular}{cc}
\hline Perlakuan & $\begin{array}{c}\text { Rerata lingkaran } \\
\text { tubuh buah terbesar } \\
(\mathrm{cm})\end{array}$ \\
\hline $\mathrm{A}(200 \mathrm{ml})$ & 1,88 \\
$\mathrm{~B}(150 \mathrm{ml})$ & 1,75 \\
$\mathrm{C}(100 \mathrm{ml})$ & 1,65 \\
$\mathrm{D}(50 \mathrm{ml})$ & 1,00 \\
\hline
\end{tabular}

Dari Tabel 3 dapat dilihat bahwa semua perlakuan memberikan pengaruh berbeda tidak nyata terhadap 
lingkaran tubuh buah jamur dimana konsntrasi air kelapa pada semua perlakuan hampir sama.

Dengan demikian, pemberian air kelapa dengan konsentrasi yang berbeda tidak berpengaruh terhadap lingkaran tubuh buah jamur yang tumbuh. Respon sangat bervariasi tergantung pada kepekaan organ tanaman. Batang merespon konsentrasi auksin dalam kisaran yang cukup lebar.

\section{B. Pembahasan}

1. Jumlah Tubuh Buah Jamur Merang Tiap Rak

Hasil penelitian menunjukan bahwa jumlah badan buah jamur merang pada setiap perlakuan berbeda. Hal ini disebabkan karena adanya perbedaan perlakuan yang diberikan pada masing-masing rak atau media tanam. Pemberian konsentrasi air kelapa harus seimbang dengan media karena semakin banyak air kelapa tidak akan baik bagi produksi jamur merang dan sebaliknya jika sedikit pemberian konsentrasi air kelapa tidak baik pula bagi produksi jamur tersebut jadi, pemberian air kelapa itu harus seimbang dengan banyaknya media yang kita gunakan.

$$
\text { Pada perlakuan C dan D }
$$

dikatakan kurang baik karena rata-rata jumlah tubuh buahnya adalah 2 dan 0,75 buah. Hal ini dikarenakan sedikitnya pemberian konsentrasi air kelapa sehingga jumlah badan buah jamur menurun. Sedangkan pada perlakuan A lebih baik dibandingkan dengan perlakuan $\mathrm{C}$ dan $\mathrm{D}$ dimana rata-rata tubuh buah jamur merang adalah 3 buah. Air kelapa memang mengandung zat/bahan-bahan seperti unsur hara, vitamin, asam amino, asam nukleat dan zat tumbuh seperti auksin dan asam giberelat yang berfungsi sebagai penstimulasi proliferasi jaringan, memperlancar metabolisme dan respirasi menurut Untari(2006) dalam Armawi (2009).

Pada perlakuan C, (air kelap 100 ml) dan perlakuan B, (air kelapa $50 \mathrm{ml}$ ) menunjukan produksi jumlah badan buah yang kurang baik, dengan nilai rata-rata $0,75-2$ buah. Hal ini disebabkan karena sedikitnya konsentrasi air kelapa yang diberikan sehingga peroduksinya tidak optimal. Pada perlakuan A (air kelapa $200 \mathrm{ml}$ ) menunjukanrata-rata jumlah tubuh buah jamur merang adalah 3 buah.

Pada perlakuan B, (air kelapa $150 \mathrm{ml}$ ) memiliki rata-rata jumlah badan buah tertinggi, dibandingkan perlakuan yang lainnya yaitu memiliki rata-rata jumlah buah sebesar 3 buah. Hal ini menunjukkan bahwa pemberian air kelapa harus seimbang dengan media tanam jamur merang. Hal ini 
karena jamur merang merupakan tumbuhan yang tidak mengandung klorofil, sehingga tidak dapat melakukan fotosintesis untuk memperoleh makanan sendiri. Untuk kehidupan dan perkembangan jamur memerlukan makanan dalam bentuk unsur kimia misalnya Natrium, Kalsium, Magnesium, Ferum, Fosfor dan Sulfur.

\section{Berat Basah Jamur Merang}

Penimbangan berat basah jamur merang dilakukan setelah pemanenan pertama terlebih dahulu. Penimbangan berturut-turut menghasilkan berat ratarata 24.98 gr, 74.15 gr, 99.9 gr, 116.55 gr pada perlakuan A, B, C, dan D. Berdasarkan hasil tersebut dapat diketahui bahwa berat basah jamur merang pada setiap perlakuan menunjukan adanya perbedaan. Suriawiria (2010)dalam Laili (1997), hal ini dipengaruhi oleh unsur hara/nutrien yang menyebabkan pertumbuhan dan perkembangan jamur merang dipengaruhi oleh empat faktor penting yaitu bibit jamur, substrat penanaman, kondisi lingkungan, dan bahan media. Substrat penanaman sangat berpengaruh terhadap perkembangan jamur karena berhubungan dengan kandungan nutrien.

3. Lingkaran Tubuh Buah Terbesar
Hasil ANOVA pemberian air kelapa terhadap lingkaran tubuh buah terbesar jamur merangdan uji lanjut yang dilakukan menunjukan hasil yang tidak berpengaruh pada setiap pelakuan. Pada perlakuan A, B, C, dan D menunjukan rata-rata masingmasing perlakuan yaitu: $1.88 \mathrm{~cm}, 1.75$ $\mathrm{cm}, 1.65 \mathrm{~cm}$, dan $1.00 \mathrm{~cm}$.

\section{KESIMPULAN}

Berdasarkan
pembahasan di atas, maka dapat
disimpulkan bahwa pemberian
konsentrasi air kelapa (Cocos nucifera
L.) memberikan pengaruh yang nyata
terhadap jumlah tubuh buah dan berat
basah, sedangkan pada lingkaran
terbesar memberikan pengaruh yang
tidak nyata pada saat satu kali panen.
Perlakuan yang memberikan pengaruh
terbaik terhadap banyaknya jumlah
tubuh buah dan berat basah jamur
merang (Volvariella volvaceae) pada
konsentrasi air kelapa 150 ml.

\section{DAFTAR PUSTAKA}

Anonimus, 2013. Air Kelapa Pemacu

Pertumbuhan dan Pembungaan Anggrek. http://ambardhi.com/anggrek/ index.html. Diakses 31 Maret 2013.

Armawi. 2009. Pengaruh Tingkat Kemasakan Buah Kelapa dan 
Konsentrasi Air Kelapa pada

Media Tanam Terhadap

Pertumbuhan Jamur Tiram

Putih (Pleurotus ostreatus)

(Skripsi). Fakultas Sains dan

Teknologi UIN Maulana

Malik Ibrahim. Malang.

Gusniwati. 2008. "Pertumbuhan dan Hasil

Tanaman Jagung Dengan

Pemberian Kompos Alangalang” “ Jurusan Budidaya Pertanian Fakultas Pertanian Jambi Kampus Pinang Masak" (Jurnal) Jambi

Indriati, G., Ningsih, L. I., \& Rizki, R. (2013). Pengaruh Pemberian Fungi Mikoriza Multispora Terhadap Produksi Tanaman Jagung (Zea mays L.). Prosiding SEMIRATA 2013, 1(1).

Laili. 1997. Pertumbuhan dan Hasil Tanaman Jamur Merang (Volvariella volvaceae Bull) Pada Beberapa Jenis Bahan Kompos Sebagae Media Tanam (Skripsi). Padang: Fakultas Pertanian Universitas Andalas.

Novi, N., \& Rizki, R. (2015). INDUKSI PEMEKARAN BUNGA (ANTHESIS) TANAMAN MELATI PUTIH (Jasminum sambac LW Ait) DENGAN PEMBERIAN

PACLOBUTRAZOL PADA BEBERAPA KONSENTRASI. Jurnal Pelangi, 7(1).

Novi, N., \& Rizki, R. (2015). TINGKAT

KOLONISASI

PERAKARAN BIBIT

PISANG JANTAN YANG

DIINOKULASI DENGAN

BEBERAPA DOSIS

INOKULAN FUNGI

MIKORIZA ARBUSKULA SERTA LAMA PEMBERIAN
FOSFAT. Jurnal

Pelangi, 6(2).

Rizki. 2011. Sistematika Tumbuhan Bahan Ajar Mata Kuliah Taksonomi Tumbuhan Tinggi. Padang: Rios Multicipta.

Rizki, R., \& Novi, N. (2017). Respon Pertumbuhan Bibit Mangrove Rhizophora Apiculata B1 pada Media Tanah Topsoil. Jurnal Bioconcetta, 3(2).

Sinaga, M. S. 2000. Jamur Merang dan Budidaya. Depok: Penebar Swadaya.

Suharjo, E. 2010. Bertanam Jamur Merang Dimedia Kardus, Limbah dan Limbah Pertanian. Jakarta: PT. Agro Media Pustaka.

Sukara, E. 1981. Cara Menanam Jamur Merang. Jakarta: Bharata Karya ksara.

Sumiati dan Djuariah. 2007. Teknologi Budidaya dan Penanganan Pascapanen Jamur Merang (Volvariella volvaceae). Bandung: Balai Penelitian Tanaman Sayuran.

Suriawiria, U. Drs. 1986. Pengantar Untuk Mengenal dan Menanam Jamur. Angkasa: Bandung.

Pusat Penelitian Karet Balai Penelitian Sembawa. 1996. Pengelolaan Alang-alang Dilahan Peta 